\title{
THE DIRECT INCIDENCE OF CORPORATE INCOME TAX
}

\author{
ON WAGES
}

\author{
Wiji Arulampalam ${ }^{+}$, Michael P. Devereux ${ }^{++}$and Giorgia Maffini ${ }^{+++}$
}

We examine the extent to which taxes on corporate income are directly shifted onto the workforce. We use data on 55,082 companies located in nine European countries over the period 1996-2003. We identify this direct shifting through cross-company variation in tax liabilities, conditional on value added per employee. Our central estimate is that the long run elasticity of the wage bill with respect to taxation is 0.093. Evaluated at the mean, this implies that an exogenous rise of $\$ 1$ in tax would reduce the wage bill by 49 cents. We find only weak evidence of a difference for multinational companies.

This version: October 2010

${ }^{+}$University Of Warwick, Oxford University Centre for Business Taxation, and the Institute for the Study of Labor (IZA), Bonn.

${ }^{++}$Oxford University Centre for Business Taxation, Institute for Fiscal Studies, CESifo, and Centre for Economic Policy Research.

${ }^{+++}$Oxford University Centre for Business Taxation and the University of Warwick.

An earlier version of this paper was circulated with the title 'The Incidence of Corporate Income Tax on Wages'. This paper was initially prepared for the European Tax Policy Forum (ETPF) conference "The Welfare Implications of International Taxation and Tax Competition”. The paper also forms part of the output of the Oxford University Centre for Business Taxation. Financial support from the Hundred Group, the ETPF and the Economic and Social Research Council (ESRC) (grant number RES-062-230163) is gratefully acknowledged. We are grateful to Steve Bond, Roger Gordon, Norman Ireland, Christian Keuschnigg, Ben Lockwood, Peter Merrill, Robin Naylor, Andrew Oswald, Helen Simpson, David Ulph, and participants at the ETPF conference, the International Institute of Public Finance (IIPF) held at Warwick, and workshops at the Universities of Oxford, St. Andrews, Vienna, and Warwick for helpful comments. We thank Socrates Mokkas for help with the data preparation. 
"On corporation tax, the Chancellor got his priorities wrong today. The public will simply not understand why, when businesses are enjoying record profits, the Chancellor found money to cut their tax payments".

"The TUC is not in favour of companies paying excessive taxes, but we do expect them to pay fair taxes". Brendan Barber, General Secretary of the UK Trades Union Congress, on the 2007 UK corporation tax cut (FT.com, 2007)

\section{INTRODUCTION}

A central issue in the distribution of tax burdens is the effective incidence of the corporation tax. This has been the subject of study for nearly 50 years in theoretical, and in Computable General Equilibrium (CGE) models. ${ }^{1}$ Nonetheless, despite its policy relevance, until very recently it received virtually no econometric investigation.

This paper re-examines the extent to which taxes on corporate income are passed on to workers in the form of lower wages. We make two main novel contributions. First, we model a new mechanism by which corporate taxes may be passed on in lower wages: the wage bargain. We differentiate two aspects of the effective incidence of the tax. Differently from previous contributions, we identify the direct incidence of the tax: given the pre-tax profit of the firm, a higher tax bill will directly reduce the quasi-rent over which the workers and the company can bargain. The indirect incidence instead has an effect on wages through determining the level of pre-tax profit, by affecting either investment or output prices. Second, we test the size of this effect using unconsolidated firm-level accounting data for over 55,000 companies in nine major European countries over the period 1996 to 2003. Variations in tax payments and effective tax rates arise due to both differences across countries and over time in the

In a 1994 survey of North American tax professionals undertaken by Slemrod (1995), 75 per cent of respondents believed that corporate income taxes are largely passed on to workers and consumers. 
legal tax system, and due to firm-specific factors. We identify the effects of taxation using all of these sources of variation.

The literature on the incidence of taxes on corporate income dates back to Harberger (1962), who developed a model of a closed economy with a corporate sector and a non-corporate sector, and analysed the introduction of a tax only in the corporate segment of the economy. Harberger (1962) showed that the incidence of the tax depended on a number of factors, including the elasticities of substitution between labour and capital used in each sector, and between the goods produced in each sector. His main conclusion was that under reasonable assumptions, the tax is borne by all owners of capital, across both segments of the economy, as it drives down the post-tax return to capital. A number of more complex CGE models with a larger number of sectors generate similar results (see, for example, Shoven, 1976).

However these results depend crucially on among other things, the assumption of a closed economy, which restricts the supply of capital to the economy. If capital is perfectly mobile between countries, but labour is not, then the results can be very different. Bradford (1978) and Kotlikoff and Summers (1987) showed that the introduction of a tax on corporate income in a home country tends to reduce the world rate of return to capital, and tends to shift capital from the home country to the rest of the world. This shift in capital reduces the return to labour in the home country, and increases the return to labour abroad. As the home country becomes small relative to the rest of the world, the effect on the world rate of return diminishes towards zero. There remains an exodus of capital, and the domestic labour force effectively bears the entire burden of the tax. Indeed given a deadweight loss induced by the outward shift of capital, the cost to the home country labour force can exceed the tax revenue generated. This suggests that a small open economy would be better off taxing immobile labour 
directly, compared to imposing a tax which distorts the allocation of capital (Gordon, 1986).

A number of recent contributions have developed more sophisticated general equilibrium models of the long-run incidence of taxes on corporate income in an open economy (Randolph, 2006; Gravelle and Smetters, 2006; and Harberger, 1995; 2006). Randolph (2006) considered a model with two countries and five sectors, with three of the sectors being taxed only in the domestic country. Of critical importance in the model are the assumptions about factor mobility, supply elasticities, and the relative capital intensities of the different sectors. Under reasonable assumptions, Randolph (2006) found that the domestic labour force and owners of domestic capital bear the tax burden roughly in proportion to their factor income shares: labour bears 73 per cent of the tax burden. Where the domestic economy is large (as for the United States), the tax also affects the foreign country by increasing wages and reducing the return to capital. Gravelle and Smetters (2006) allowed for a form of imperfect competition with the possibility that tradable goods are not perfect substitutes across countries. This effectively reduces the mobility of capital, and increases the extent to which owners of capital bear the tax burden.

Of course these models exclude several factors that may be important. In a recent survey, Auerbach (2006) noted a number of such factors including dynamics, investment incentives, corporate financial policy, choice of organisational form and alternative forms of imperfect competition. In this paper, we extend the literature by drawing on many studies of wage determination to investigate how taxes on corporate income can play a role in the wage bargain. Instead of making the simple assumptions that the aggregate stock of labour is fixed, and that labour is paid its marginal product, we investigate the wage bargain at the firm level. To do so, we introduce a tax on 
corporate income into the basic efficient bargaining framework of McDonald and Solow (1981), in which the firm and the labour force bargain over both wages and employment.

This generates a previously unexplored channel through which corporate taxes can affect wages. Companies operating in imperfect competition may bargain over the proportion of quasi-rents paid out in wages. We introduce into the bargain a standard tax on domestic corporate income, which is levied on profit net of wages and an allowance for capital expenditure. We refer to the impact of the tax through the wage bargain itself - conditional on value added - as a direct effect, which reduces the size of the quasi-rent available to bargain over. Our model specification enables us to identify this effect empirically at the level of an individual firm. We distinguish this from indirect effects of the tax, which can arise through two channels. First, there may be an effect of a change in the tax liability on the output price, conditional on capital and labour. Second, a change in tax may affect the incentive to invest and hence the capital stock, and indirectly the labour force. Both of these may affect the pre-tax level of value added. $^{2}$ The second effect determines the size of the deadweight cost arising from distortions to the behaviour of the company as a result of the tax.

Our paper builds on an empirical literature investigating the extent to which wages are partly determined by sharing in quasi-rents. ${ }^{3}$ Part of this literature examined the extent to which rents generated by technological innovation are passed on in higher wages; for example, Van Reenen (1996) followed both a reduced form and a structural approach to examine this question. Like Abowd and Lemieux (1993), Van Reenen (1996) emphasised the importance of dealing with the endogeneity of quasi-rents.

\footnotetext{
2 In an international context, wage bargaining may give a firm an incentive to generate outside options in the form of foreign investment. See, for example, the model by Eckel and Egger (2006).

3 In a recent contribution, using similar data to this paper, Budd, Konings, and Slaughter (2005) investigated whether wages are determined as a share of parent-firm profit as well as subsidiary profit.
} 
Dealing with endogeneity appropriately can significantly raise the estimated proportion of quasi-rents passed on to the workforce. Our estimates of the elasticity of wage payments with respect to value added are broadly in line with those in the literature.

Other recent papers have also aimed to provide empirical evidence of the incidence of taxes on corporate income. ${ }^{4}$ Hassett and Mathur (2006) use aggregate wage and tax data from 72 countries over the period 1981-2002. They find that wages are highly responsive to the corporate tax rate, and more so in small countries. One element of this approach is surprising however. In most of its empirical formulations, the paper adds controls, including a measure of value added per worker in the manufacturing sector. This control is unlikely to be independent of the effects of the tax on corporate income, which the authors are seeking to identify: a higher tax rate should generate a net outflow of capital, which is likely to depress value added per worker. These results therefore effectively abstract from indirect effects through changes in value added.

Desai, Foley, and Hines (2007) use aggregate data on the activities of US companies in around 50 countries in four years to estimate jointly the impact of the corporate income tax on the wage rate and the rate of profit. Fixing the sum of these effects to be unity, they find results of a similar magnitude to Randolph (2006): between 45 and 75 per cent of the corporate tax borne is borne by labour with the remainder falling on capital. Fixing the sum of the effects to be unity also appears to abstract from the indirect effects of the deadweight cost, which if included would generate a total effect in excess of unity.

Felix and Hines (2009) follow an approach closer to that used in this paper, using individual level data to investigate the effects of US state level corporation tax on the wage differential between workers who belong to unions and those who do not.

\footnotetext{
4 A survey of this literature is provided in Gentry (2007).
} 
Consistent with unions bargaining over quasi rents, they find that a higher corporation tax rate is associated with a lower union differential.

Our empirical analysis differs from these papers in several important respects. We exploit within-firm and cross-firm variation in taxation using firm-level data. We use a panel of unconsolidated firm-level accounting data for just over 55,000 companies in Belgium, Finland, France, Germany, Italy, the Netherlands, Spain, Sweden and the United Kingdom over the period 1996-2003. Controlling for labour productivity (and hence for the effects of the corporate tax through capital) and other relevant company characteristics, we examine whether firms with a higher tax liability pay lower wages, ceteris paribus. Analysing this variation enables us to identify the direct effect of the tax on wages, while controlling for other effects through the pre-tax level of profit. It does not allow us to identify the scale of indirect effects.

We are able to identify the direct effects of taxation by exploiting firm- and time-specific variation in the tax liability. We therefore do not have to rely solely on changes in the statutory tax system. Tax liabilities can vary across firms with similar levels of profit because of diversity in the form of their economic activity, such as the assets invested in and the sources of finance used, the extent to which profits are shifted between subsidiaries, the extent of losses brought forward from earlier periods, and a number of other reasons. We use lagged values of firm-specific variables based on these factors as instruments for the endogenous tax liability.

Using micro data also allows us to exploit companies’ heterogeneity to analyse whether the incidence of the corporate income tax differs according to the type of firm. For example, multinational corporations may differ from domestic companies because they have the option to relocate part or all of their productive activity abroad. Moreover, firms in multinational groups are more likely to shift profit to lower tax jurisdictions. 
This may increase their bargaining power, as well as reducing the location-specific profit over which they would be prepared to bargain.

We provide rigorous empirical evidence that, in this bargaining framework, a significant part of the corporation income tax is passed on to the labour force in the form of lower wages. Our central estimates show that, conditional on value added per employee, in the long run and evaluated at the mean, an exogenous $\$ 1$ increase in the tax bill tends to reduce real wages by 49 cents. ${ }^{5}$ Our bargaining model indicates that the effective incidence of an exogenous \$1 rise in pre-tax value added should be lower than this, since a rise in pre-tax value added is partly shared by the government in higher taxes. In fact, our empirical results indicate that, evaluated at the mean, the effective incidence of an exogenous \$1 rise in pre-tax value added is around 25 cents, which is broadly consistent with the theoretical model.

The paper is organised as follows. Section I develops the conceptual framework, which allows us to consider the impact of corporate income taxes on the determination of wages, and to differentiate their direct and indirect effects. Section II presents the data used in the empirical section. Section III discusses various econometric issues, and Section IV presents the results. Section V concludes.

\section{CONCEPTUAL FRAMEWORK}

We employ a simple model to inform the empirical work reported below. We consider the case of a single firm. The wage rate, $w$, and the labor force, $N$, are set through efficient bargaining between the firm and a single union representing all the workers in the company. Simultaneously, the firm chooses its capital, $K$. The model is

\footnotetext{
5 Calculations are based on the estimated long run elasticity of -0.076 and are detailed in Section IV.C.
} 
similar to many used in the literature (see references in Blanchflower, Oswald, and Sanfey, 1996; Addison and Schnabel, 2003).

Employees have an outside wage available, $\bar{w}$. This may reflect the wage rate in an alternative job, or unemployment benefit: It is unaffected by the bargain. The union aims to maximize $(u(w)-u(\bar{w})) N$, where $u($.$) represents the utility of a single worker$ and $N$ is the number of workers employed by the firm.

The firm may have the option of shifting its activities to another location, or another activity, where, net of the costs of shifting, it can earn an outside post-tax profit of $\Pi^{*}$. The firm is prepared to bargain over location-specific profit (before wages) that is, the additional profit available by producing locally. Domestic post-tax profit is

$$
\Pi=F(K, N)-w N-r K-T .
$$

$F(K, N)$ is a standard revenue function, depending on capital, labor, and the output price. We interpret $F$ as value added. The cost of capital is $r K$. Corporation tax, levied at rate $\tau$, is denoted $T$ and defined as

$$
T=\tau\{F(K, N)-w N-\alpha r K\}+\phi .
$$

Thus, the tax is levied on revenue net of wage payments and an allowance for the cost of capital, where $\alpha$ is a measure of the generosity of depreciation allowances. In addition, however, there are many other factors, which can affect the firm's tax position. These include, for example: the size of interest payments, the allocation across types of investment which receive different capital allowances, the existence of losses brought forward from an earlier period, the extent to which taxable profit can be shifted abroad to a lower-tax country through manipulating transfer prices, stock relief, or contributions to an investment reserve or pension fund. We do not explicitly model these factors; rather we include them all in the term $\phi$. The existence of this term 
implies that tax liabilities may vary across firms that have the same revenue, wage payments and investment. In the empirical work, it is the existence of the factors incorporated in $\phi$ which allow us to identify the effects of tax independently of $F{ }^{6}$

The bargaining power of the firm, $\mu$, may depend on the cost of a temporary dispute with the workforce. The bargaining power of the union is $(1-\mu)$; this may depend on the availability of alternative income to the workers in the event of a dispute.

We assume that wages and employment are determined by a Nash bargain, which maximizes: ${ }^{7}$

$$
B=\{[u(w)-u(\bar{w})] N\}^{(1-\mu)}\{\Pi-\Pi *\}^{\mu} .
$$

where $\pi$ is defined by (1) and (2). The first order conditions for maximization are:

$$
\begin{aligned}
& (1-\mu) \frac{u^{\prime}(w)}{u(w)-u(\bar{w})}-\mu\left\{\frac{N(1-\tau)}{\Pi-\Pi^{*}}\right\}=0, \text { and } \\
& F_{N}(K, N)=w-\frac{(1-\mu)}{\mu}\left\{\frac{\Pi-\Pi^{*}}{N(1-\tau)}\right\} .
\end{aligned}
$$

Finally, the firm chooses its capital stock by maximizing net of tax profit, $\Pi$. This yields the familiar expression:

$$
F_{K}(K, N)=(1+m) r
$$

where $m$ is the effective marginal tax rate (EMTR), $m=\tau(1-\alpha) /(1-\tau)$. The three expressions (4), (5) and (6) jointly determine the values of the wage rate, $w$, the capital stock, $K$, and the number of workers employed, $N$.

$6 \quad$ We assume that the additional factors determining the tax liability in the outside option are not captured exactly by $\phi$. If they were, then this term would drop out of the wage bargain. This is reasonable if the outside option is to shift production abroad where there is a different tax system. If the outside option is undertaken by the same domestic firm, then some elements of $\phi$ (for example, losses brought forward from earlier periods) could be common with the outside option.

7 Partly based on the empirical results of Budd, Konings, and Slaughter (2005), Riedel (2008) presents a wage-bargaining model in which the bargain is over the sum of the parent firm's profit and the subsidiary's profit. This model predicts that a higher domestic tax rate would tend to increase domestic wages, because it would reduce the cost to the domestic subsidiary of paying wages while not reducing the size of the aggregate profit. Our approach is similar to that of Goerke (1996). 
To investigate the role of tax in affecting these three variables, we expand $u(w)$ around the observed wage $w: u(\bar{w}) \cong u(w)+u^{\prime}(w)(\bar{w}-w)$. Making this approximation and substituting into (4) generates

$$
w \cong \bar{w}+\frac{(1-\mu)}{\mu(1-\tau)}\{\pi-\pi *\}
$$

where $\pi=\Pi / N$ represents profit per worker and $\pi^{*}=\Pi * / N$ represents the value of the outside option per worker. In general, we use the lower case to denote values per worker, and $\tilde{\phi}=\phi / N$. Expression (7) is a standard expression: the wage rate is equal to the outside wage, plus a share of the quasi-rent per worker.

Before identifying the impact of taxation on the wage rate, first consider the effect of an exogenous change in output per worker, $f=F / N$, (or equivalently in this model, value added per worker) holding $k, \pi^{*}$ and $\widetilde{\phi}$ constant. Using (1), (2) and (7), it is straightforward to show that

$$
\frac{d w}{d f}=1-\mu ; \frac{d \pi}{d f}=\mu(1-\tau) ; \text { and } \frac{d t}{d f}=\mu \tau
$$

These three effects sum to 1 . That is, the exogenous increase of $\$ 1$ in value added is shared between the three participants: workers, shareholders, and the government. Note that the share received by the workforce is unaffected by the tax rate: this reflects the fact that wages are deductible in determining taxable profit.

Now consider an exogenous change in $\tilde{\phi}$, holding $f, k$ and $\pi^{*}$ constant. This measures the impact on wages of a lump-sum change in taxation, holding the activities of the company fixed. It is straightforward to show:

$$
\frac{d w}{d \widetilde{\phi}}=-\frac{1-\mu}{1-\tau} ; \frac{d \pi}{d \widetilde{\phi}}=-\mu ; \text { and } \frac{d t}{d \widetilde{\phi}}=\frac{1-\mu \tau}{1-\tau}
$$


These three expressions sum to zero: a rise in $\tilde{\phi}$ increases the tax liability, a cost which is shared between the workforce and shareholders. Under the same conditions, holding $f, k$ and $\pi^{*}$ constant, we also have

$$
\frac{d w}{d t}=-\frac{1-\mu}{1-\mu \tau} ; \text { and } \frac{d \pi}{d t}=-\frac{\mu(1-\tau)}{1-\mu \tau}
$$

These two effects sum to -1: holding other things constant, an increase in the tax liability of $\$ 1$ is shared between the workforce and the shareholders.

Holding $f, k$ and $\pi^{*}$ constant, we define $d w / d t$ to be the direct incidence of corporation tax on the wage rate and $d \pi / d t$ to be the direct incidence of corporation tax on net profit per worker. That is, we define the direct incidence of corporation tax to measure the effect of an exogenous change in tax (generated by an exogenous change in $\tilde{\phi}$ ) through the wage bargain, holding all the other activities of the company fixed.

These concepts are clearly different from the usual concept of the total incidence of the tax. This would allow for the company to respond to a change in taxation by changing its input factors, $N$ and $K$, and output price, all affecting $F$, and would also allow for general equilibrium effects through $\bar{w}$ and $\pi^{*}$. Such effects may arise through a reform to $m$ and $\tau$, as well as $\phi$. We do not derive nor estimate expressions for the total incidence in this paper.

\section{Empirical Model}

Instead, in this paper we aim to estimate the direct incidence of corporation tax on the wage rate. We adapt the empirical literature on wage determination in bargaining by estimating a model in which the average wage rate of individual companies is specified as a function of value added per worker and tax per worker, as well as other 
factors designed to capture the effects of the alternative wage and the outside option of the shareholders. Our main innovation is to include the tax term directly in the model where value added per worker is also present. The presence of $\phi$ implies that there can be variation in the tax liability independent of an effect through $F / N$, which allows us to identify the effects of taxation. (Note that we do not observe $\phi$, but only the overall tax liability). By conditioning on $F / N$, we restrict ourselves to examining the direct incidence.

Because of the potential endogeneity of the tax liability, we instrument this term using two sets of instruments. One measures the legal parameters of the tax system, and so is common to all companies in the same country and year. The other depends on firm-specific tax liability. These include the use of debt finance, the makeup of capital expenditure, and the extent to which losses from previous periods may be used to reduce current liabilities. We use country-time-sector specific measures of the minimum wage and union density to capture outside option for the workers and relative bargaining power respectively.

In the empirical estimation, we also consider heterogeneity across firms. In particular, we compare firms that are part of multinational groups with purely domestic companies. In the model, there are two reasons why these may behave differently. First, the outside option of the multinational $\pi^{*}$ may be higher, implying that the size of the profit over which the firm is prepared to bargain is lower. This is difficult to test: the outside option cannot be observed since the firm does not in practice choose it. In the empirical estimation, we therefore cannot include the outside option. This means that we may over-estimate the size of the profit over which the firm is willing to bargain and that the degree of overestimation is higher for multinational firms. This may induce 
greater negative bias in the estimated coefficients for firms that are part of multinational groups.

As a possible proxy for the outside option, we experiment by including the value added and tax of the rest of the multinational group. As a proxy for the outside option, these variables would tend to have a negative impact on the wage. However, as Budd, Konings, and Slaughter (2005) and Riedel (2008) argue, it is also possible that domestic workers bargain over the entire firm's profit, rather than only on the part earned domestically. In this case, these group variables would have a positive impact on the domestic wage.

A second element of heterogeneity between firms is that a multinational may also find it cheaper to transfer production to another plant temporarily while engaged in a dispute with the workforce. This would tend to increase the firm's bargaining power, $\mu$, as it can be more patient in waiting to achieve a deal, compared with a firm which does not have this opportunity. This effect can be examined by testing whether the coefficients from the bargaining equation - which reflect bargaining strength - differ between these two groups of firms.

Note that the model predicts that a higher bargaining power of the firm would result in the firm paying a smaller share of any additional profit to the workforce through higher wages. Given the symmetry in the model across all cash flows within the firm, this also implies that a firm with higher bargaining power would respond to an increase in tax by passing a smaller proportion of the increase onto the workforce. From equation (9), we have:

$$
\frac{\partial(\partial w / \partial t)}{\partial \mu}=\frac{\mu(1-\tau)}{(1-\mu \tau)^{2}}>0 .
$$


That is, as the bargaining power of the firm increases, the coefficient on the tax per employee term should rise - that is, a multinational which has greater bargaining power should have a smaller coefficient in absolute terms.

Finally, note that in the empirical work below, we do not attempt to identify the indirect effect of taxes through the effective marginal tax rate and the capital stock, or through an effect of $\phi$ on prices, conditional on capital and labor. To evaluate the former would mean that we could not include other firm-level variables as controls in the equation, since all of them would be affected by the size of the capital stock.

\section{DATA}

The empirical analysis is carried out using ORBIS, compiled by the Bureau van Dijk (2007). It consists of accounting data from the balance sheet and profit and loss account of companies all around the world from 1996 to 2005. In addition our dataset contains information on the ownership structure of the firms in 2005, including the number of shareholders, their names, their country of residence and their percentage interest in the company, and the number of subsidiaries, their names, and the percentage participation of the parent company.

Initially, we selected only the companies not defined as 'micro' in European Commission (2003). ${ }^{8}$ This sample was further restricted as follows. First, it was limited to companies for which unconsolidated data and ownership information were available; our interest is in the determination of wages at the level of an individual company, rather than at the level of a group of companies. Second, observations which showed clear errors and missing values were dropped, along with observations in the first and

8 Selecting non-micro companies involved selecting only companies with at least two subsequent years of recorded total assets greater than $€ 2,000$ and at least one employee. 
one hundredth percentiles of the distribution for the main variables. ${ }^{9}$ Finally, the dynamic model specification and the method of estimation we used required companies with at least four continuous years of data. The final sample consists of 55,082 companies located in Belgium, Finland, France, Germany, Italy, the Netherlands, Spain, Sweden, and the United Kingdom.

We used ownership information from the original full set of data to identify companies in the same group in our sample. Companies were classified as: (i) belonging to a multinational group if they were connected to at least one other company in a different country by an ownership link of at least 50 per cent of the capital; (ii) belonging to a domestic group if the company was connected to other companies by an ownership link of at least 50 per cent but with none of those companies located in a different country; or (iii) as a stand-alone company if it did not have any ownership links with other companies.

Table I illustrates the distribution of companies across the nine countries. It also shows the number of companies that are stand-alone (overall around 35 per cent), part of a domestic group (30 per cent), or part of a multinational group (35 per cent). Table II indicates the number of observations used in the estimation for each company. Over 15,000 companies (over one quarter of the sample of companies used) have data for eight years; a similar number of companies have either six or seven observations. Table III shows the number of observations per year used in the regressions; each year is well represented.

The main variables are wage rate, number of employees, fixed assets per employee, tax bill per employee, and value added per employee. 


\section{ECONOMETRIC SPECIFICATION AND VARIABLES USED}

The conceptual framework in Section I, and in particular the discussion in the Empirical Model section, leads to a specification for wages of the form

$$
w=w(f, \mu, \bar{w}, \tilde{\phi})
$$

where $f=$ value added per employee, $\mu=$ relative bargaining power, $\bar{w}=$ outside option for workers and $\tilde{\phi}=$ variables to capture the tax liabilities of the firms. We proxy the wage rate by the annual average company wage (that is, costs of employees (435) divided by the total number of employees (425)). ${ }^{10}$ We assume that a worker could move to take up a job in the worst paid company in the same broad industrial sector ${ }^{11}$, the same country, and the same year; we take this to be the outside wage in that sector, country, and year. We use the ORBIS measure of value added (439) divided by the total number of employees to proxy $f$. To capture the union relative bargaining power, we use union density (UD) using a country- and year-specific index from the OECD (2004).

As discussed in Section I, $\tilde{\phi}$ is not observed in our dataset. We therefore proxy this using the tax variable recorded in the profit and loss statement (430). This is our measure of the tax liability of the firm in each period. ${ }^{12}$ This measure is company and time-specific, in that the tax liability depends on many factors specific to the firm's performance in any particular period. We treat the tax liability as endogenous. We use two different sets of instruments. The first set includes the country and year-specific measures of the effective marginal tax rate (EMTR), the effective average tax rate

10. This is the only measure of wage available in the dataset. The variable codes in ORBIS are given in parenthesis in bold.

11 The broad industrial sector is defined using the NACE Rev 1.1 core codes at the 2-digit level.

12 This is an approximation, since firms may record a value for the tax liability which differs from their obligation to the tax authorities; however, there is no reason to believe that there should be a systematic bias in using this measure. 
$(\mathrm{EATR})^{13}$ and the statutory corporate tax rate $\tau$. These measures are based on the legal tax system, and so are unlikely to be affected by the shocks to the individual firm's profit and wages. The second set of instruments is a collection of lagged time-varying firm-specific variables. We use the ratio of tangible fixed assets (406) to total fixed assets (408) as an indicator of the likely value of depreciation allowances for tax purposes. Non-current liabilities (416) as a proportion of total assets are employed as an indicator for the extent to which taxable income is likely to be reduced by interest payments. We also use a binary indicator of whether profit before taxes in previous periods was negative, which may indicate that the company has brought forward taxable losses to set against current profit to reduce current tax liabilities.

All monetary variables are deflated to 2000 prices using OECD country- and year-specific consumer price indexes, and converted to a common currency (US dollars) using the year 2000 OECD national average exchange rates. ${ }^{14}$ Table IV displays some basic descriptive statistics for the main variables and instruments.

Finally to account for adjustment lags, we specify a general dynamic model of the form

$$
w_{i t}=\sum_{j=1}^{2} \gamma_{j} w_{i, t-j}+\sum_{j=0}^{2} \beta_{j} x_{i, t-j}+\alpha_{i}+\alpha_{t}+\varepsilon_{i t}
$$

where $i$ and $t$ index companies and years respectively and $w$ is log wage rate. Log value added per employee and variables that are associated with wage bargaining such as outside wage and union density are also in $x$. About 15 per cent of our sample observations contain either a negative or a zero value for the tax liability. We assume that the effect of the tax burden on the wage rate is only present when there are positive taxes, so we include log tax liability per employee only when it is positive. To account

\footnotetext{
13 These are calculated according to the methodology proposed by Devereux and Griffith (2003), and are computed from a number of sources.

14 OECD CPIs and exchange rates are taken from www.OECDStat.org
} 
for the observations with non-positive taxes, we include in $x$ a dummy variable indicating a non-positive tax liability. $\alpha_{i}$ is a company-specific fixed effect, $\alpha_{t}$ is a year effect that captures common macroeconomic shocks, and $\varepsilon_{i t}$ is the error term. We start from the general dynamic model and use rigorous testing procedures to arrive at a more parsimonious representation. ${ }^{15}$

Several econometric issues need to be considered before a choice of an appropriate technique is made for the estimation of a dynamic equation of this form. Due to the presence of permanent company-specific unobserved heterogeneity $\left(\alpha_{i}\right)$ which is correlated with the lagged dependent variables and endogenous regressors (value added per worker, tax liability per worker, and the outside wage), the pooled OLS and within-group (WG) estimators are inconsistent. It is well recognised in the literature that the most appropriate technique to use in this case is the Generalised Method of Moments (GMM) applied to the first-differenced equation that does not contain $\alpha_{i}$. The precise set of moment conditions that should be used to generate the appropriate instruments depends on the assumptions about the correlation between the regressors and the composite error term $u_{i t}=\alpha_{i}+\varepsilon_{i t} \cdot{ }^{16}$ Much of the recent literature has focused on finding appropriate instruments for the application of GMM. Arellano and Bond (1991) (AB) proposed the use of lagged levels of the variables as instruments for the endogenous differences in the first-differenced model [GMM-diff]. However, later research (for example, Blundell and Bond, 1998 (BB)) has shown that when the series are highly persistent, the levels instruments are weak predictors of the differenced endogenous variables. Therefore, the $\mathrm{AB}$ estimator can have very poor finite sample properties in terms of bias and precision. BB proposed the use of additional moment

\footnotetext{
15 The above general dynamic specification can also be derived from a static model with an $\operatorname{AR}(2)$ process for the disturbance.

16 We accommodate the time effects using year dummies.
} 
conditions that correspond to the use of lagged differences of endogenous variables as instruments for the model in levels. This GMM estimator is known as system GMM [GMM-sys]. It combines moment conditions for the model in first differences with the moment conditions for the model in levels. BB and Blundell, Bond, and Windmeijer (2000) showed that the system GMM estimator had better finite sample properties than AB's original differenced GMM estimator. They advocated the use of this technique when the series were highly persistent. However, this relied on certain stationarity conditions of the initial observation. Bunn and Windmeijer (2010) showed that when the variance of the unobserved heterogeneity $\alpha_{i}$ is high relative to the variance of the idiosyncratic error $\varepsilon_{i t}$, the performance of the system GMM deteriorates. In summary, whether one uses GMM-diff, or GMM-sys, or even some other method of estimation will depend on the statistical properties of the variables used in the model. Our choice of instruments for our GMM estimation has been based on this discussion. We shall return to the issue of appropriate instruments later when we discuss the results.

We have used two tests to investigate the validity of our chosen instruments. The first is the Sargan/Hansen test for over-identification (Sargan, 1958; Hansen, 1982) which requires a non-rejection of the null hypothesis being tested. The second is a serial correlation test (Arellano and Bond, 1991) that tests for the presence of serial correlation in the first differenced errors $\varepsilon_{i t}$. White noise errors $\varepsilon_{i t}$ would imply an MA(1) process for the $\Delta \varepsilon_{i t}$, thus rejecting the null of no first order serial correlation but not rejecting the null of second order serial correlation. We use xtabond2 (Roodman, 2009a) in StataCorp (2009) to estimate our models using the GMM technique. 


\section{RESULTS}

\section{IV.A Basic Results}

Table V presents results for our basic specification using different estimators. This specification includes only value-added per employee and the tax bill per employee. All specifications include time dummies and two lags of each variable. Since the preferred specification required two lags of each variable, we have estimated the same model using different methods to illustrate the effect of choice of technique on the estimated coefficients. Column (1) presents the results from a pooled OLS regression. There is no allowance for company-specific unobservables in this specification, although the standard errors are clustered to account for this. Columns (2) and (3) present results from the WG estimation (OLS on variables entered in mean deviations) and OLS on the first-differenced data respectively. These are two alternative ways of dealing with company-specific unobservables in the estimation. Generally, in the absence of endogenous regressors, the pooled OLS estimator of the coefficient of the lagged dependent variable is upward-biased, while the WG and the OLS on the firstdifferenced estimators are downward-biased estimates (Blundell, Bond and Windmeijer, 2000). The coefficient estimates on the lagged dependent variables are very different in the three model estimations and are consistent with these biases. Both the pooled OLS and the WG estimates of the coefficient on $w_{i t-1}$ are positive, though of very different magnitudes. The first-differenced OLS model estimate of this coefficient is negative. Surprisingly, all other coefficient estimates are very similar.

GMM estimation results are provided in columns (4) to (8). The sets of instruments used in these specifications are different. As noted above, all sets of instruments include country- and time-specific measures of the effective marginal tax rate (EMTR), the effective average tax rate (EATR), and the statutory corporate tax rate. 
Also included are the following time-varying firm-specific variables in logs: tangible fixed assets as a proportion of total fixed assets, non-current liabilities as a proportion of total assets, and an indicator variable for non-positive profit before tax. Indicator variables to pick up zero values of the logged variables were also included in the set of instruments. Columns (4) and (5) are based on the AB GMM-diff estimation of the firstdifferenced equation using levels of the endogenous variables as additional instruments. Columns (6) and (7) are based on the BB GMM-sys estimation, which uses levels (firstdifferences) of the endogenous variables as instruments for the first-differenced (levels) endogenous variables.

One practical problem with both approaches is that the number of instruments can be numerous. Unlike in two-stage-least-squares (2SLS) where the estimation sample is restricted according to the choice of lag for the instrument, in standard applications of GMM-diff and GMM-sys, a separate instrument is included for each time period. To illustrate this problem, consider our application where $\mathrm{T}=8$. If we were to apply 2SLS to estimate (12) in first-differences, $w_{i t-3}$ can be used as an instrument for $\Delta w_{i t-1}$ under standard assumptions. This would imply that the estimation sample would be $t=4, . ., 8$. However, every additional lag of our dependent variable that is included in the set of instruments would result in the loss of one extra time observation. In our sample where the number of companies is large, every loss of a time observation results in a loss of around 55,000 observations per period. In contrast, the standard GMM-diff and GMM-sys approaches include separate instruments for each time period. This results in a sparse instrument set but a larger estimation sample. Three practical 
problems can result from the use of a sparse instrument set (Roodman 2009b). ${ }^{17}$ First, the instruments can be too weak to identify the relevant effects. Second, the precision of the weighting matrix that is used in the GMM estimation is affected. Third, the Sargan/Hansen test has low power. Given these problems, we also investigate the approach in a strand of the literature where the standard GMM-diff instruments are combined through addition to create a smaller instrument set (Roodman 2009a, 2009b). ${ }^{18}$ Columns (4) and (6) present results from the GMM estimation that used the full set of unrestricted instruments, while columns (5) and (7) present results from estimation that used the smaller restricted instrument set.

However, in all cases, the Sargan/Hansen test for over-identification is rejected and the tests for first and second order serial correlations are rejected, implying a problem with the estimators. ${ }^{19}$ The table reports that the degrees of freedom for the over-identifying tests in the case of the restricted instrument matrix are much smaller. However, the tests still reject the null of instrument validity. ${ }^{20}$

17 Taking a simple example to illustrate this issue, consider an $\operatorname{AR}(1)$ specification in first-difference as follows: $\Delta y_{i t}=\gamma \Delta y_{i t-1}+\Delta \varepsilon_{i t}$, and the model would be estimated using $t=3, . . T$. The instrument matrix for the $i$ the company in the case of AB-diff would be: $Z_{i}=\left[\begin{array}{ccccccc}y_{i 1} & 0 & 0 & 0 & 0 & 0 & 0 \ldots \\ 0 & y_{i 1} & y_{i 2} & 0 & 0 & 0 & 0 \ldots \\ 0 & 0 & 0 & y_{i 1} & y_{i 2} & y_{i 3} & 0 \ldots \\ . & . & . & . & . & . & . \\ . & . & . & . & . & . & .\end{array}\right]$.

For example, the instruments for the observation $y_{i 3}-y_{i 2}$ would be $y_{i 2}$ and $y_{i 1}$.

18 This is achieved in STATA using the 'collapse' option in estimation command xtabond2. Taking the example given in footnote 20, the new instrument matrix would be $Z_{i}=\left[\begin{array}{ccc}y_{i 1} & 0 & 0 \\ y_{i 2} & y_{i 1} & 0 \\ y_{i 3} & y_{i 2} & y_{i 1} \\ . & . & .\end{array}\right]$.

In Table A.I of the Appendix, we have provided the results from OLS and WG estimations of simple univariate $\operatorname{AR}(1)$ and $\operatorname{AR}(2)$ models. The results are not suggestive of a near unit root in the two main variables $w$ and $v$. Hence, the need for the estimation of the model using GMM-sys is not present. When we used the GMM-diff estimator, we were only able to find a reasonable specification which passed all the model diagnostics when we used lags 5 or more as instruments. This resulted in a drastic loss of observations and we therefore did not pursue this strategy.

20 Bunn and Windmeijer (2010) showed that when the variance of the unobserved company-specific heterogeneity $\left(\alpha_{i}\right)$ relative to the variance of $\varepsilon_{i t}$ increases, the bias in the GMM-sys can become quite high compared to the GMM-diff estimator and they advocate the use of GMM-diff in this case. 
We next turn to our preferred estimates, which are provided in column (8) of Table V. These results refer to the GMM estimation of the first differenced equation using a set of first differenced instruments. Using a general notation, in the example of footnote 20, the instrument matrix for this GMM estimation is as follows:

$$
Z_{i}=\left[\begin{array}{cccc}
0 & 0 & 0 & 0 \\
y_{i 2}-y_{i 1} & 0 & 0 & 0 \\
y_{i 3}-y_{i 2} & y_{i 2}-y_{i 1} & 0 & 0 \\
y_{i 4}-y_{i 3} & y_{i 3}-y_{i 2} & y_{i 2}-y_{i 1} & 0 \\
. & . & . & .
\end{array}\right] .
$$

We treat all lags from two upwards of all our variables as being predetermined. The columns of the above matrix refer to the different instruments used.

Unlike the results in columns (4) to (7) of Table V, for the specification shown in column (8), the tests for over-identification and the tests for first and second order serial correlations are all satisfactory. The Sargan/Hansen test for over-identification is not rejected. The test for first order serial correlation is rejected, while the test for second order serial correlation is not. This is what we would expect if the errors in the levels equation were not serially correlated.

Turning to the coefficient estimates, the estimated effects are broadly consistent with the conceptual framework presented in Section I, even though we have added dynamics in the empirical specification. Both the first period and second period lagged wage rate terms have a significant effect on the current wage rate, after controlling for company-specific unobservables and accounting for endogeneity of the regressors. There is some persistence but it is not very high; the coefficients are smaller than the GMM-diff and GMM-sys estimates but are larger than the WG estimates in column (2). The short-run elasticity of the wage rate with respect to the tax per employee is quite large compared to other columns; it is estimated to be -0.095 in column (8), about six times those reported in columns (1) to (3). The long-run elasticity is a little lower at - 
0.066. Note the coefficient on the value added per employee variable is not the elasticity with respect to this variable as changes in this variable will also have an effect via the tax per employee variable in the wage equation. Adjusting for this effect, the short-run elasticity with respect to value added per employee is estimated to be 0.459 , and the longer run is again slightly higher at $0.511 .^{21}$ We explore below the implications of these results for the incidence of the tax.

\section{IV.B. Basic Specification with Bargaining Variables}

In Table VI, we use the same estimator as in column (8) of Table V, but add variables associated with union bargaining. The new variables include a measure of country- and year-specific aggregate union density, and a measure of the outside option available to the workers. ${ }^{22}$ As a proxy for the latter, we use the minimum of the log wage per employee in that sector and country in a particular year. We also include a dummy for those companies that pay the minimum wage.

For ease of exposition, column (8) of Table V is reproduced in column (1) of Table VI. We add the extra variables one at a time: column (2) includes the aggregate union density variable and column (3) includes additionally the outside-option variables. Since these variables do not vary by company, they are unlikely to have a very strong effect. This is what we find, although the coefficients have the correct sign. Including these additional controls has little impact on the other coefficients and standard errors. The diagnostic tests change a little: in particular the Sargan/Hansen statistic no longer rejects the null at $10 \%$. The estimated short-run elasticity of the tax variable is now slightly higher; for example, in column (3) it is -0.120 . The union density variable is correctly signed and is positive and significant at $5 \%$.

\footnotetext{
21 The elasticity is calculated at the sample averages using the derivation provided in Appendix 1.

22 Although union coverage would be a better measure of union strength, we were unable to obtain consistent data series for our sample of countries for the years we have used. Hence, we include union density as a proxy for the strength of the union in these countries.
} 
In summary, the basic specification results displayed in column (8) of Table V do not change much with the addition of variables associated with the bargaining strength. Below, we use column (3) of Table VI as our preferred model for further investigations to examine the behaviour of multinationals compared to domestic companies.

\section{IV.C. Evaluating the Direct Incidence}

As already noted, the elasticity of the wage rate with respect to the tax liability per employee is a little higher with the additional bargaining variables. In column (1) of Table VI, the short-run elasticity is estimated at -0.095 and the long-run elasticity at about -0.066 . In column (3), the short-run elasticity is -0.120 and the long-run elasticity is -0.093 .

Since the wage rate is calculated as total compensation per employee, these estimates are equivalent to the elasticity of total compensation with respect to the tax liability. To use these results to identify the direct incidence of tax, it is useful to

calculate the impact of an exogenous $\$ 1$ change in the tax liability on total compensation. Calculations using the derivations in the Appendix 1 and evaluated at the sample averages are presented in Table VII. Based on the column (3) estimates, a \$1 increase in the tax liability leads to a 64 cents reduction in total compensation in the short run, and a 49 cents reduction in the long run. Standard errors are given in parentheses.

Recall that these are estimates only of the direct effects of an increased tax liability. They do not include any indirect effect through prices or the capital stock, since we are controlling for pre-tax value added per employee. Note also that we would not expect over-shifting in the direct effect, which simply measures the distribution of a given location-specific profit between the firm and the workers. 
It is also interesting to compare the effects of taxation and value added. Following the same procedure as above, Table VII indicates that the short run incidence is 0.222 : that is, a rise of $\$ 1$ in value added would increase wage payments by 22 cents. The long-run rise is similar at 25 cents. From section I, we would expect the incidence of the tax to be higher than the incidence of a change in the pre-tax value added; the theory would suggest that the impact of an exogenous \$1 increase in value added would need to be grossed up by a factor $(1-\mu \tau)$ (see equations (8) and (10)) to find the expected impact of an exogenous \$1 reduction in tax. Our long-run estimate of 25 cents is within one standard error of the estimate of tax incidence of 0.49 evaluated at the average statutory tax rate of 0.35 .

The estimates in Table VII are based on the expressions in the Appendix 1, using means of wage payments, tax and value added over the whole of the sample. An alternative approach would be to use means only over those observations with positive tax payments (over which the coefficient on the tax liability is derived). This approach generates estimates of the long run incidence of taxation of -0.39 (standard error, 0.129 ) and of value added of 0.27 (0.03). This is a smaller effect of taxation, but a larger effect of value added: in this case, the relationship between the two estimates is closer to that expected from the theory discussed above. ${ }^{23}$

\section{IV.D Behaviour of Multinationals}

Finally, we consider two forms of heterogeneity across firms, both of which involve multinational companies. Both are based on the specification of Table VI column (3) (which is reproduced in column (1) of Table VIII for ease of reference).

\footnotetext{
23 A further approach would be to compute the incidence for each observation. The median of the resulting distribution for the incidence of taxation is approximately -1 , indicating that, at the median, the entire increase in tax would be passed on in lower wages.
} 
First, we investigate whether the estimated parameters differ according to whether a firm is part of a multinational group or not. The conceptual framework in Section I indicated that the stronger the bargaining power of a firm, the lower the proportion of profit before wages that would be passed on to the labour force, and symmetrically, the lower the proportion of any increase in tax that would be passed on to the labour force. To consider differences in bargaining power, we investigate two sub-samples of the data: in column (2), we consider only stand-alone firms and in columns (3) and (4), we consider only firms, which are part of multinational groups.

The short-run elasticities of the wage rate with respect to tax per employee are very similar for the two groups of companies (column 2 vs column 3 in Table VIII), whilst the long-run elasticity is larger for international groups (-0.108 for multinationals versus -0.076 for stand-alones). These are provided in Table VII. The long-run incidence of an exogenous $\$ 1$ rise in tax is thus slightly higher for multi-national group of companies, with compensation falling by 54 cents for employees of multinational groups and by 43 cents for stand-alone companies.

By contrast, for value added, both the short and the long run elasticities are higher for the stand-alone companies relative to multinational group. The long-run incidence of an extra $\$ 1$ of value added is lower for companies that are part of multinational groups. However, none of these differences between the two groups of companies are statistically significant.

A second effect for multinationals could occur through the outside option. In column (5) we investigate this for multinational companies by including the tax and value added variables for the rest of the multinational group. The group variables are calculated aggregating values over all of the other subsidiaries of the group for which we have data. We express these aggregates as a proportion of the number of the original 
company's employees. If these terms proxy the outside option of the group, then a higher value added (or lower tax) in the rest of the group may indicate a more valuable outside option and hence a lower domestic wage.

In fact, we do not find any significant effects of these variables. This may of course simply indicate that they are not good proxies for the firm's outside options. Such lack of significance also differs from the results of Budd, Konings, and Slaughter (2005) and Riedel (2008). They find the opposite effect for the value added of the parent firm. The value added of the parent has a positive effect on the wage in the subsidiary. They attribute this to the domestic labour force bargaining over profits in the parent as well as in the subsidiary. However, neither paper includes the tax or value added of the rest of the multinational group, but only the parent. The lack of significance in our results may be due to this difference in our approach. More generally, it may reflect the possibility that the workers may bargain over worldwide profits, a factor that offsets the use of worldwide profit as a proxy for the outside option in the bargain.

\section{CONCLUSION}

The standard model of a small open economy yields strong results for the effective incidence of a tax on capital located in that country. Given a fixed world rate of return, a tax will raise the pre-tax rate of return, but leave the post-tax rate of return unaffected. The rise in the pre-tax rate of return is achieved by an outflow of capital, which reduces labour productivity and hence the compensation received by the immobile domestic labour force. There is therefore a presumption that the burden of the tax will be shifted away from the owners of capital to the labour force.

In this paper, we investigate empirically part of this effect. Specifically, in our estimation we analyse the impact of a change in taxation conditional on value added. We interpret this in the context of a wage bargaining model: for a given pre-tax quasi- 
rent, a higher tax reduces the post-tax quasi-rent available to be bargained over by the firm and the employees. This wage bargain introduces a direct channel by which taxation affects the wage rate, a channel which can be estimated conditional on the value added of the firm. We estimate the size of this direct effect using a large database of over 55,000 companies in nine countries over the period 1996 to 2003.

We do not estimate the indirect effect of a change in tax, which affects the wage rate through changing the size of the pre-tax quasi-rent available to be bargained over. More specifically, although by controlling for value added (as an estimate of the pre-tax quasi-rent) we estimate the impact of changes in value added on the wage rate, we do not estimate the impact of the tax on the size of value added. By excluding this effect, our estimate of the direct effect can be interpreted as excluding the effects associated with the deadweight cost of the tax, and any changes in output price.

The results strongly support the hypothesis of a direct effect of corporate income tax through wage bargaining. Our results suggest that approximately 50 per cent of an exogenous increase in tax is passed on in lower wages in the long run. These estimates are for the direct effect of the tax only, conditional on value added (and hence indirectly conditional on investment); they are additional to possible indirect effects through value added.

We also investigate whether the incidence of the corporate income tax on the wage rate differs between stand-alone companies and companies that are part of multinational groups. We do not find any significant difference between the two groups. Nor do we find any effect on the wage rate of the profit or tax liability elsewhere in the multinational group. 


\section{REFERENCES}

Abowd, John M. and Thomas Lemieux. (1993). The Effects of Product Market Competition on Collective Bargaining Agreements: The Case of Foreign Competition in Canada, Quarterly Journal of Economics, 108, 983-1014.

Addison, John T. and Claus Schnabel. (2003). International Handbook of Trade Unions (Cheltenham: Edward Elgar Publishing).

Arellano, Manuel, and Stephen R. Bond. (1991). Some Tests of Specification for Panel Data: Monte Carlo Evidence and an Application to Employment Equations, Review of Economic Studies, 58, 277-297.

Auerbach, Alan J. (2006). Who Bears the Corporate Tax? A Review of What We Know, in Tax Policy and the Economy, Vol. 20, ed. James M. Poterba, (Cambridge: MIT Press).

Blanchflower, David G., Andrew J. Oswald and Peter Sanfey. (1996). Wages, Profits and Rent-Sharing, Quarterly Journal of Economics, 111, 227-250.

Blundell, Richard and Stephen R. Bond. (1998). Initial Conditions and Moment Restrictions in Dynamic Panel Data Models, Journal of Econometrics, 87, 115-143.

Blundell, Richard, Stephen R. Bond and Frank Windmeijer. (2000). Estimation in Dynamic Panel Data Models: Improving on the Performance of the Standard GMM Estimator, in Nonstationary Panels, Panel Cointegration, and Dynamic Panels, in Advances in Econometrics, Vol. XV, Badi Baltagi, ed. (Amsterdam: JAI Press, Elsevier Science).

Bradford, David F. (1978). Factor Prices may be Constant, but Factor Returns are not, Economics Letters, 1, 199-203.

Budd, John W., Josef Konings, and Matthew J. Slaughter. (2005). Wages and International Rent-Sharing in Multinational Firms, Review of Economics and Statistics, 87, 73-84.

Bunn, Maurice J.G. and Frank Windmeijer. (2010). The Weak Instrument Problem of the System GMM Estimator in Dynamic Panel Data Models, Econometrics Journal, 13(1), 95-126.

Bureau van Dijk, ORBIS Database. (2007). http://www.bvdep.com/en/ORBIS.html 
Desai, Mihir. A., C. Fritz Foley and James R. Hines. (2007). Labor and Capital Shares of the Corporate Tax Burden: International Evidence, mimeo, ITPF and UrbanBrookings Tax Policy Center Conference of Who pays the Corporate Tax in an Open Economy?

Devereux, Michael P. and Rachel Griffith. (1998). Taxes and the Location of Production: Evidence from a Panel of US Multinationals, Journal of Public Economics, 68, 335-367.

Devereux, Michael P. and Rachel Griffith. (2003). Evaluating Tax Policy for Location Decision, International Tax and Public Finance, 10, 107-126.

Eckel, Carsten and Hartmut Egger. (2006). Wage Bargaining and Multinational Firms in General Equilibrium, CESifo Working Paper No. 1711.

European Commission. (2003). Commission Recommendation of 6 May 2003 Concerning the Definition of Micro, Small and Medium-Sized Enterprises. Official Journal of the European Commission May. 2003/361/EC. (Brussels: Commission of the European Communities).

Felix, Alison R. and James R. Hines. (2009). Corporate Taxes and Union Wages in the United States. NBER Working Paper 15263.

FT.com. (2007). Budget Verdict: Instant Reaction, (London: The Financial Times Ltd, 21 March 2007). www.ft.com

Gentry, William. M. (2007). A Review of the Evidence on the Incidence of the Corporate Income Tax, US Department of the Treasury, Office of Tax Analysis Paper No. 101.

Goerke, Laszlo. 1996. Taxes on Payroll, Revenues and Profits in Three Models of Collective Bargaining, Scottish Journal of Political Economy, 43, 549-565.

Gordon, Roger. H. (1986). Taxation of Investment and Savings in a World Economy, American Economic Review, 76, 1086-1102.

Gravelle, Jane G. and Kent A. Smetters. (2006). Does the Open Economy Assumption really mean that Labor bears the Burden of a Capital Income Tax? in Advances in Economic Analysis and Policy, Vol. VI(I), (Berkeley: Berkeley Electronic Press) 1548-1548. 
Hansen, Lars P. (1982). Large Sample Properties of Generalised Method of Moment Estimators. Econometrica, Vol. 50 (1982), 1029-1054.

Harberger, Arnold C. (1962). The Incidence of the Corporation Income Tax, Journal of Political Economy, 70, 215-240.

Harberger, Arnold C. (1995). The ABCs of Corporation Tax Incidence: Insights into the Open-Economy Case, in Tax Policy and Economic Growth, (Washington, D.C.: American Council for Capital Formation Center for Policy Research), 51-73.

Harberger, Arnold C. (2006). Corporation Tax Incidence: Reflections on what is Known, Unknown and Unknowable, in Fundamental Tax Reform: Issues, Choices, and Implications, John W. Diamond and George R. Zodrow, ed. (Cambridge: MIT Press, 2006).

Hassett, Kevin A. and Aparna Mathur. (2006). Taxes and Wages, American Enterprise Institute Working Paper 128.

Kotlikoff, Laurence J., and Lawrence H. Summers. (1987). Tax Incidence, In $\underline{\text { Handbook }}$ of Public Economics, Vol. 2, Alan J. Auerbach and Martin Feldstein, eds. (Amsterdam: Elsevier Science, North-Holland), 1043-1092.

McDonald, Ian M. and Robert M. Solow. (1981). Wage Bargaining and Employment, American Economic Review, 71, 896-908.

Nickell, Stephen J., and Sushil Wadhwani. (1990). Insider Forces and Wage Determination, Economic Journal, 100, 496-509.

OECD. (2004). Employment Outlook (Paris: OECD Publishing).

OECD. (2006). Employment Outlook (Paris: OECD Publishing).

Randolph, William G. (2006). International Burdens of the Corporate Income Tax, Congressional Budget Office Working Paper No. 09.

Riedel, Nadine. (2008). Taxing Multinational under Union Wage Bargaining, mimeo, University of Munich.

Roodman, David. (2009a). How to do Xtabond2: An Introduction to Difference and System GMM in Stata. Stata Journal, 9(1), 86-136.

Roodman, David. (2009b). A Short Note on the Theme of too Many Instruments, Oxford Bulletin of Economics and Statistics, 71(1),135-158. 
Sargan, Denis J. (1958). The Estimation of Economic Relationships using Instrumental Variables, Econometrica, 26, 393-415.

Shoven, John B. (1976). The Incidence and Efficiency Effects of Taxes on Income from Capital, Journal of Political Economics, 84, 1261-1283.

Slemrod, Joel. (1995). Professional Opinions about Tax Policy, National Tax Journal 48, 121-147.

StataCorp. (2009). Stata Statistical Software: Release 11, (College Station, TX: StataCorp LP).

Van Reenen, John. (1996). The Creation and Capture of Rents: Wages and Innovation in a Panel of UK Companies, Quarterly Journal of Economics 111, 195-226. 
Table I

Number and Type of Company, by Country

\begin{tabular}{|c|c|c|c|c|c|}
\hline \multirow[t]{2}{*}{ Country } & \multicolumn{4}{|c|}{ Number of companies } & \multirow{2}{*}{$\begin{array}{l}\text { Number of } \\
\text { observatio } \\
n s\end{array}$} \\
\hline & Total & $\begin{array}{l}\text { Stand- } \\
\text { alone }\end{array}$ & $\begin{array}{c}\text { Part of domestic } \\
\text { groups }\end{array}$ & $\begin{array}{c}\text { Part of } \\
\text { multinationals }\end{array}$ & \\
\hline Belgium & 1,954 & 224 & 453 & 1,277 & 3,408 \\
\hline Finland & 1,023 & 91 & 467 & 465 & 2,833 \\
\hline France & 17,505 & 4,894 & 5,645 & 6,966 & 54,511 \\
\hline Germany & 168 & 24 & 19 & 125 & 319 \\
\hline Italy & 8,483 & 3,212 & 2,775 & 2,496 & 29,021 \\
\hline The Netherlands & 303 & 10 & 32 & 261 & 911 \\
\hline Spain & 13,704 & 6,873 & 3,906 & 2,925 & 42,367 \\
\hline Sweden & 2,713 & 99 & 1,053 & 1,561 & 5,964 \\
\hline United Kingdom & 9,229 & 3,972 & 1,985 & 3,272 & 27,415 \\
\hline Total & 55,082 & 19,399 & 16,335 & 19,348 & 166,749 \\
\hline
\end{tabular}

Table II

Number of Observations per Company

\begin{tabular}{c|cc}
\hline \hline \multirow{2}{*}{$\begin{array}{c}\text { Years available } \\
\text { per firm }\end{array}$} & \multicolumn{2}{|c}{ Number of companies } \\
\cline { 2 - 3 } & Frequency & Per cent \\
\hline $\mathbf{4}$ & 12,261 & 22.3 \\
$\mathbf{5}$ & 12,217 & 22.2 \\
$\mathbf{6}$ & 7,667 & 13.9 \\
$\mathbf{7}$ & 7,632 & 13.8 \\
$\mathbf{8}$ & 15,305 & 27.8 \\
Total & $\mathbf{5 5 , 0 8 2}$ & $\mathbf{1 0 0}$ \\
\hline \hline
\end{tabular}

Table III

Observations per Year

\begin{tabular}{c|cc}
\hline \hline Years & Frequency & Per cent \\
\hline $\mathbf{1 9 9 9}$ & 24,087 & 14.5 \\
$\mathbf{2 0 0 0}$ & 30,614 & 18.4 \\
$\mathbf{2 0 0 1}$ & 32,848 & 19.7 \\
$\mathbf{2 0 0 2}$ & 38,527 & 23.1 \\
$\mathbf{2 0 0 3}$ & 40,673 & 24.4 \\
Total & $\mathbf{1 6 6 , 7 4 9}$ & $\mathbf{1 0 0}$ \\
\hline \hline
\end{tabular}


Table IV

Descriptive Statistics for Main Variables and Instruments (in levels)

\begin{tabular}{|c|c|c|c|c|c|c|c|c|c|c|c|c|c|}
\hline & & $\begin{array}{c}\text { Wage } \\
\text { rate }\end{array}$ & $\begin{array}{c}\text { Value } \\
\text { added } \\
\text { per } \\
\text { employee }\end{array}$ & $\begin{array}{c}\text { Tax bill } \\
\text { per } \\
\text { employee }\end{array}$ & $\begin{array}{c}\text { Negative } \\
\text { tax bill } \\
\text { (dummy) }\end{array}$ & $\begin{array}{c}\text { Union } \\
\text { density }\end{array}$ & $\begin{array}{c}\text { Outside } \\
\text { wage } \\
\text { rate }\end{array}$ & $\begin{array}{c}\text { Tangible } \\
\text { fixed assets/ } \\
\text { fixed assets }\end{array}$ & $\begin{array}{c}\text { Non current } \\
\text { liabilities/ } \\
\text { total assets }\end{array}$ & $\begin{array}{c}\text { Negative } \\
\text { profit } \\
\text { before tax } \\
\text { (dummy) }\end{array}$ & EMTR & EATR & $\begin{array}{c}\text { Statutory } \\
\text { tax rate }\end{array}$ \\
\hline \multirow{2}{*}{ Belgium } & Median & 48.45 & 78.05 & 4.54 & 0 & 55.6 & 17.69 & 0.86 & 0.10 & 0 & 0.06 & 0.30 & 0.40 \\
\hline & S.D. & 17.11 & $1,300.09$ & 56.03 & 0.35 & 0.25 & 7.97 & 0.35 & 0.17 & 0.36 & 0 & 0 & 0 \\
\hline \multirow[t]{3}{*}{ Finland } & Mean & 41.97 & 110.42 & 14.34 & 0.14 & 74.71 & 7.57 & 0.65 & 0.17 & 0.18 & 0.15 & 0.24 & 0.29 \\
\hline & Median & 39.75 & 60.76 & 3.32 & 0 & 74.8 & 5.82 & 0.78 & 0.10 & 0 & 0.15 & 0.25 & 0.29 \\
\hline & S.D. & 13.41 & 233.6 & 52.58 & 0.35 & 0.6 & 6.01 & 0.33 & 0.20 & 0.39 & 0.01 & 0.01 & 0 \\
\hline \multirow[t]{3}{*}{ France } & Mean & 42.94 & 81.58 & 7.16 & 0.18 & 8.22 & 2.48 & 0.65 & 0.11 & 0.20 & 0.14 & 0.30 & 0.37 \\
\hline & Median & 39.01 & 53.52 & 2.49 & 0 & 8.2 & 0.42 & 0.75 & 0.06 & 0 & 0.14 & 0.29 & 0.35 \\
\hline & S.D. & 17.15 & 359.98 & 46.71 & 0.39 & 0.09 & 3.49 & 1.75 & 0.16 & 0.40 & 0.01 & 0.02 & 0.03 \\
\hline \multirow[t]{3}{*}{ Germany } & Mean & 57.51 & 137.17 & 14.92 & 0.08 & 23.42 & 13.41 & 0.69 & 0.29 & 0.21 & 0.19 & 0.32 & 0.39 \\
\hline & Median & 54.79 & 90.25 & 5.46 & 0 & 23.2 & 8.91 & 0.84 & 0.24 & 0 & 0.19 & 0.31 & 0.38 \\
\hline & S.D. & 18.73 & 168.19 & 33.33 & 0.27 & 0.99 & 12.14 & 0.33 & 0.20 & 0.41 & 0.03 & 0.04 & 0.05 \\
\hline \multirow[t]{2}{*}{ Italy } & Mean & 32.58 & 76.13 & 10 & 0.03 & 34.68 & 11.82 & 0.69 & 0.13 & 0.18 & 0.19 & 0.35 & 0.43 \\
\hline & S.D. & 9.3 & 205.54 & 30.05 & 0.16 & 0.82 & 9.84 & 0.30 & 0.13 & 0.39 & 0.04 & 0.04 & 0.05 \\
\hline \multirow[t]{3}{*}{ The Netherlands } & Mean & 53.95 & 209.43 & 64.1 & 0.23 & 22.82 & 14.56 & 0.81 & 0.15 & 0.21 & 0.15 & 0.28 & 0.35 \\
\hline & Median & 51.49 & 83.93 & 7.28 & 0 & 22.5 & 11.6 & 1.00 & 0.06 & 0 & 0.15 & 0.29 & 0.35 \\
\hline & S.D. & 16.6 & 817.05 & 521.39 & 0.42 & 0.76 & 8.79 & 0.31 & 0.20 & 0.40 & 0 & 0 & 0 \\
\hline \multirow[t]{3}{*}{ Spain } & Mean & 31.77 & 78.02 & 9.44 & 0.18 & 16.19 & 1.25 & 0.70 & 0.14 & 0.17 & 0.18 & 0.29 & 0.35 \\
\hline & Median & 29.21 & 48.77 & 2.95 & 0 & 16.2 & 1.12 & 0.82 & 0.07 & 0 & 0.18 & 0.29 & 0.35 \\
\hline & S.D. & 13.66 & 225.86 & 38.56 & 0.38 & 0.08 & 1.47 & 0.31 & 0.33 & 0.37 & 0 & 0 & 0 \\
\hline \multirow[t]{3}{*}{ Sweden } & Mean & 36.51 & 96.08 & 10 & 0.26 & 78.12 & 4.27 & 0.72 & 0.25 & 0.23 & 0.11 & 0.23 & 0.28 \\
\hline & Median & 34.34 & 54.18 & 3.07 & 0 & 78 & 3.14 & 0.90 & 0.18 & 0 & 0.11 & 0.23 & 0.28 \\
\hline & S.D. & 11.02 & 500.9 & 53.41 & 0.44 & 0.34 & 4.99 & 0.34 & 0.25 & 0.42 & 0 & 0 & 0 \\
\hline \multirow[t]{3}{*}{ United Kingdom } & Mean & 35.92 & 77.26 & 6.4 & 0.18 & 29.43 & 1.62 & 0.91 & 0.14 & 0.15 & 0.17 & 0.26 & 0.30 \\
\hline & Median & 33.55 & 48.26 & 2.22 & 0 & 29.3 & 1.1 & 1.00 & 0.07 & 0 & 0.16 & 0.26 & 0.30 \\
\hline & S.D. & 15.36 & 347.05 & 28.83 & 0.38 & 0.23 & 2.24 & 0.23 & 0.19 & 0.36 & 0.01 & 0.01 & 0.01 \\
\hline
\end{tabular}


Table V

Wage Equation Model Estimates (standard errors ${ }^{\mathrm{ii}}$ )

\begin{tabular}{|c|c|c|c|c|c|c|c|c|}
\hline Dependent variable: $\log$ (wage rate) & $\begin{array}{l}\text { OLS - } \\
\text { levels }\end{array}$ & $\begin{array}{c}\text { Within } \\
\text { Group (FE) }\end{array}$ & $\begin{array}{c}\text { OLS - } \\
\text { first } \\
\text { difference } \\
\\
(3) \\
\end{array}$ & $\begin{array}{l}\text { GMM-diff } \\
\text { AB - full } \\
\text { instrument } \\
\text { matrix } \\
(4) \\
\end{array}$ & $\begin{array}{c}\text { GMM-diff AB } \\
\text { - restricted } \\
\text { instrument } \\
\text { matrix } \\
(5) \\
\end{array}$ & $\begin{array}{l}\text { GMM-sys } \\
\text { BB- full } \\
\text { instrument } \\
\text { matrix } \\
(6) \\
\end{array}$ & $\begin{array}{c}\text { GMM-sys } \\
\text { BB- restricted } \\
\text { instrument } \\
\text { matrix } \\
(7) \\
\end{array}$ & $\begin{array}{l}\text { GMM - uses } \\
\text { restricted first } \\
\text { difference } \\
\text { Instruments } \\
\text { (8) }\end{array}$ \\
\hline $\log ($ wage rate $) \quad t-1$ & $\begin{array}{l}0.665^{* * *} \\
(0.006)\end{array}$ & $\begin{array}{l}0.044^{* * *} \\
(0.008)\end{array}$ & $\begin{array}{c}-0.302^{* * *} \\
(0.006)\end{array}$ & $\begin{array}{l}0.146^{* * *} \\
(0.009)\end{array}$ & $\begin{array}{l}0.236^{* * *} \\
(0.012)\end{array}$ & $\begin{array}{l}0.419^{* * *} \\
(0.009)\end{array}$ & $\begin{array}{c}0.449^{* * *} \\
(0.010)\end{array}$ & $\begin{array}{l}0.121^{* * *} \\
(0.022)\end{array}$ \\
\hline$t-2$ & $\begin{array}{l}0.200^{* * * *} \\
(0.005)\end{array}$ & $\begin{array}{l}-0.020^{* * *} \\
(0.004)\end{array}$ & $\begin{array}{c}-0.111^{* * *} \\
(0.004)\end{array}$ & $\begin{array}{l}0.052^{* * *} \\
(0.005)\end{array}$ & $\begin{array}{l}0.076^{* * *} \\
(0.005)\end{array}$ & $\begin{array}{l}0.157^{* * *} \\
(0.005)\end{array}$ & $\begin{array}{l}0.152^{* * *} \\
(0.006)\end{array}$ & $\begin{array}{l}0.029^{* * *} \\
(0.010)\end{array}$ \\
\hline Log (tax per employee) & $\begin{array}{l}-0.016^{* * *} \\
(0.001)\end{array}$ & $\begin{array}{l}-0.014^{* * *} \\
(0.001)\end{array}$ & $\begin{array}{l}-0.013^{* * * *} \\
(0.001)\end{array}$ & $\begin{array}{l}-0.014 \\
(0.011)\end{array}$ & $\begin{array}{c}0.011 \\
(0.020)\end{array}$ & $\begin{array}{l}-0.169^{* * *} \\
(0.009)\end{array}$ & $\begin{array}{l}-0.191^{* * *} \\
(0.012)\end{array}$ & $\begin{array}{l}-0.095^{* * *} \\
(0.034)\end{array}$ \\
\hline$t-1$ & $\begin{array}{c}0.005^{* * *} \\
(0.001)\end{array}$ & $\begin{array}{l}-0.001^{*} \\
(0.001)\end{array}$ & $\begin{array}{l}-0.005^{* * *} \\
(0.001)\end{array}$ & $\begin{array}{l}-0.002 \\
(0.004)\end{array}$ & $\begin{array}{l}-0.008 \\
(0.007)\end{array}$ & $\begin{array}{l}0.039^{* * *} \\
(0.004)\end{array}$ & $\begin{array}{l}0.048^{* * *} \\
(0.005)\end{array}$ & $\begin{array}{l}0.033^{* * *} \\
(0.010)\end{array}$ \\
\hline$t-2$ & $\begin{array}{c}0.000 \\
(0.001)\end{array}$ & $\begin{array}{l}-0.004^{* * * *} \\
(0.001)\end{array}$ & $\begin{array}{l}-0.002^{* * * *} \\
(0.000)\end{array}$ & $\begin{array}{l}-0.001 \\
(0.001)\end{array}$ & $\begin{array}{l}-0.003^{*} \\
(0.002)\end{array}$ & $\begin{array}{l}0.010^{* * *} \\
(0.002)\end{array}$ & $\begin{array}{l}0.012^{* * *} \\
(0.002)\end{array}$ & $\begin{array}{l}0.006^{* * *} \\
(0.002)\end{array}$ \\
\hline Dummy: neg or zero tax bill & $\begin{array}{l}0.064^{* * *} \\
(0.002)\end{array}$ & $\begin{array}{l}0.067^{* * *} \\
(0.002)\end{array}$ & $\begin{array}{l}0.059^{* * *} \\
(0.002)\end{array}$ & $\begin{array}{l}0.249^{* * *} \\
(0.042)\end{array}$ & $\begin{array}{c}0.313^{* * *} \\
(0.069)\end{array}$ & $\begin{array}{l}0.190^{* * *} \\
(0.040)\end{array}$ & $\begin{array}{c}0.121^{* *} \\
(0.050)\end{array}$ & $\begin{array}{l}0.386^{* * *} \\
(0.078)\end{array}$ \\
\hline$t-1$ & $\begin{array}{l}-0.032^{* * *} \\
(0.002)\end{array}$ & $\begin{array}{l}0.007^{* * *} \\
(0.002)\end{array}$ & $\begin{array}{l}0.021^{* * *} \\
(0.002)\end{array}$ & $\begin{array}{l}-0.063^{* * *} \\
(0.011)\end{array}$ & $\begin{array}{l}-0.071^{* * *} \\
(0.016)\end{array}$ & $\begin{array}{l}-0.121^{* * *} \\
(0.011)\end{array}$ & $\begin{array}{l}-0.110^{* * *} \\
(0.013)\end{array}$ & $\begin{array}{l}-0.096^{* * *} \\
(0.019)\end{array}$ \\
\hline$t-2$ & $\begin{array}{l}-0.008^{* * *} \\
(0.002)\end{array}$ & $\begin{array}{l}0.012^{* * *} \\
(0.002)\end{array}$ & $\begin{array}{l}0.009^{* * *} \\
(0.001)\end{array}$ & $\begin{array}{l}-0.017^{* * *} \\
(0.003)\end{array}$ & $\begin{array}{l}-0.016^{* * *} \\
(0.004)\end{array}$ & $\begin{array}{l}-0.044^{* * *} \\
(0.004)\end{array}$ & $\begin{array}{l}-0.040^{* * *} \\
(0.005)\end{array}$ & $\begin{array}{l}-0.012^{* *} \\
(0.005)\end{array}$ \\
\hline Log (value added per employee) & $\begin{array}{l}0.265^{* * *} \\
(0.005)\end{array}$ & $\begin{array}{l}0.281^{* * *} \\
(0.007)\end{array}$ & $\begin{array}{l}0.264^{* * *} \\
(0.005)\end{array}$ & $\begin{array}{l}0.756^{* * *} \\
(0.025)\end{array}$ & $\begin{array}{l}0.621^{* * *} \\
(0.044)\end{array}$ & $\begin{array}{l}1.121^{* * *} \\
(0.013)\end{array}$ & $\begin{array}{l}1.082^{* * * *} \\
(0.016)\end{array}$ & $\begin{array}{l}0.773^{* * *} \\
(0.069)\end{array}$ \\
\hline$t-1$ & $\begin{array}{l}-0.161^{* * * *} \\
(0.005)\end{array}$ & $\begin{array}{l}0.013^{* * *} \\
(0.004)\end{array}$ & $\begin{array}{l}0.092^{* * *} \\
(0.003)\end{array}$ & $\begin{array}{l}-0.149^{* * *} \\
(0.012)\end{array}$ & $\begin{array}{l}-0.163^{* * *} \\
(0.014)\end{array}$ & $\begin{array}{l}-0.432^{* * *} \\
(0.010)\end{array}$ & $\begin{array}{l}-0.418^{* * *} \\
(0.012)\end{array}$ & $\begin{array}{l}-0.136^{* * *} \\
(0.021)\end{array}$ \\
\hline$t-2$ & $\begin{array}{l}-0.049^{* * *} \\
(0.003)\end{array}$ & $\begin{array}{c}0.023^{* * *} \\
(0.003)\end{array}$ & $\begin{array}{l}0.041^{* * *} \\
(0.002)\end{array}$ & $\begin{array}{l}-0.034^{* * *} \\
(0.005)\end{array}$ & $\begin{array}{l}-0.034^{* * *} \\
(0.005)\end{array}$ & $\begin{array}{l}-0.131^{* * *} \\
(0.006)\end{array}$ & $\begin{array}{l}-0.122^{* * *} \\
(0.007)\end{array}$ & $\begin{array}{l}-0.022^{* * *} \\
(0.008)\end{array}$ \\
\hline $\begin{array}{l}\text { Hansen Test for over-identification } \\
\text { (Degrees of freedom) }\end{array}$ & & & & $\begin{array}{l}526.24 \\
(172)\end{array}$ & $\begin{array}{c}166.64 \\
(46)\end{array}$ & $\begin{array}{l}1191.31 \\
(227)\end{array}$ & $\begin{array}{l}653.68 \\
(56)\end{array}$ & $\begin{array}{l}45.64 \\
(37)\end{array}$ \\
\hline $\begin{array}{l}\text { [p-value] } \\
A R(1)\end{array}$ & -13.17 & & -11.08 & $\begin{array}{l}{[0.000]} \\
-22.40\end{array}$ & $\begin{array}{r}{[0.000]} \\
-17.93\end{array}$ & $\begin{array}{r}{[0.000]} \\
-29.94\end{array}$ & $\begin{array}{r}{[0.000]} \\
-28.92\end{array}$ & $\begin{array}{c}{[0.156]} \\
-13.99\end{array}$ \\
\hline [p-value $]$ & {$[0.000]$} & & {$[0.000]$} & {$[0.000]$} & {$[0.000]$} & {$[0.000]$} & {$[0.000]$} & {$[0.000]$} \\
\hline $\begin{array}{l}\text { AR(2) } \\
\text { [p-value }]\end{array}$ & $\begin{array}{l}-10.97 \\
{[0.000]}\end{array}$ & & $\begin{array}{c}-5.42 \\
{[0.000]}\end{array}$ & $\begin{array}{c}-3.21 \\
{[0.001]}\end{array}$ & $\begin{array}{c}-2.95 \\
{[0.003]}\end{array}$ & $\begin{array}{c}-3.14 \\
{[0.002]}\end{array}$ & $\begin{array}{c}-2.90 \\
{[0.004]}\end{array}$ & $\begin{array}{c}-1.23 \\
{[0.219]}\end{array}$ \\
\hline
\end{tabular}




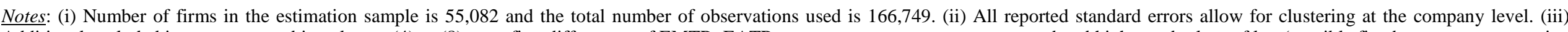

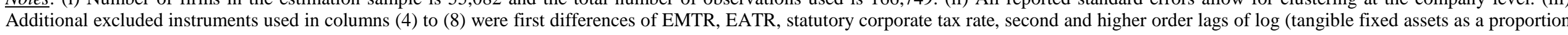

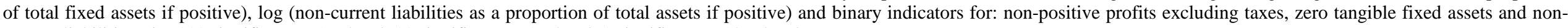
current liabilities; (iv) ${ }^{* * *}$ significant at $1 \%$ level; ** significant at $5 \%$ level; * significant at $10 \%$ level 
Table VI

Extensions to the Basic Specification (Column (8) from Table V)

\begin{tabular}{|c|c|c|c|}
\hline Dependent variable: $\log$ (wage rate) & $\begin{array}{c}\text { Basic } \\
\text { specification } \\
\\
(1) \\
\end{array}$ & $\begin{array}{c}\text { Basic } \\
\text { specification } \\
\& \\
\text { Union density } \\
(2) \\
\end{array}$ & $\begin{array}{c}\text { Basic specification } \\
\& \\
\text { All bargaining } \\
\text { variables } \\
(3) \\
\end{array}$ \\
\hline Log(wage rate) & & & \\
\hline$t-1$ & $\begin{array}{l}0.121^{* * *} \\
(0.022)\end{array}$ & $\begin{array}{l}0.116^{* * *} \\
(0.024)\end{array}$ & $\begin{array}{l}0.135^{* * *} \\
(0.024)\end{array}$ \\
\hline$t-2$ & $\begin{array}{l}0.029^{* * *} \\
(0.010)\end{array}$ & $\begin{array}{l}0.024^{* *} \\
(0.011)\end{array}$ & $\begin{array}{l}0.031^{* * *} \\
(0.011)\end{array}$ \\
\hline Log (tax per employee) & $\begin{array}{l}-0.095^{* * *} \\
(0.034)\end{array}$ & $\begin{array}{l}-0.118^{* * * *} \\
(0.035)\end{array}$ & $\begin{array}{l}-0.120^{* * *} \\
(0.037)\end{array}$ \\
\hline$t-1$ & $\begin{array}{l}0.033^{* * *} \\
(0.010)\end{array}$ & $\begin{array}{l}0.036^{* * * *} \\
(0.010)\end{array}$ & $\begin{array}{l}0.036^{* * *} \\
(0.010)\end{array}$ \\
\hline$t-2$ & $\begin{array}{l}0.006^{* * *} \\
(0.002)\end{array}$ & $\begin{array}{l}0.007^{* * *} \\
(0.003)\end{array}$ & $\begin{array}{l}0.007^{* * *} \\
(0.003)\end{array}$ \\
\hline Dummy: negative or zero tax bill & $\begin{array}{l}0.386^{* * *} \\
(0.078)\end{array}$ & $\begin{array}{l}0.376^{* * * *} \\
(0.091)\end{array}$ & $\begin{array}{l}0.361^{* * *} \\
(0.088)\end{array}$ \\
\hline$t-1$ & $\begin{array}{l}-0.096^{* * *} \\
(0.019)\end{array}$ & $\begin{array}{l}-0.094^{* * *} \\
(0.021)\end{array}$ & $\begin{array}{l}-0.089^{* * * *} \\
(0.021)\end{array}$ \\
\hline$t-2$ & $\begin{array}{l}-0.012^{* *} \\
(0.005)\end{array}$ & $\begin{array}{l}-0.012^{* *} \\
(0.006)\end{array}$ & $\begin{array}{l}-0.011^{*} \\
(0.006)\end{array}$ \\
\hline Log (value added per employee) & $\begin{array}{l}0.773^{* * *} \\
(0.069)\end{array}$ & $\begin{array}{l}0.849^{* * * *} \\
(0.069)\end{array}$ & $\begin{array}{l}0.889^{* * *} \\
(0.067)\end{array}$ \\
\hline$t-1$ & $\begin{array}{l}-0.136^{* * *} \\
(0.021)\end{array}$ & $\begin{array}{l}-0.145^{* * *} \\
(0.023)\end{array}$ & $\begin{array}{l}-0.155^{* * *} \\
(0.023)\end{array}$ \\
\hline$t-2$ & $\begin{array}{l}-0.022^{* * *} \\
(0.008)\end{array}$ & $\begin{array}{l}-0.023^{* *} \\
(0.009)\end{array}$ & $\begin{array}{l}-0.025^{* * *} \\
(0.009)\end{array}$ \\
\hline Union Density & & $\begin{array}{l}0.012^{* * *} \\
(0.006)\end{array}$ & $\begin{array}{l}0.013^{* *} \\
(0.006)\end{array}$ \\
\hline$t-1$ & & $\begin{array}{l}-0.005 \\
(0.004)\end{array}$ & $\begin{array}{c}0.003 \\
(0.006)\end{array}$ \\
\hline$t-2$ & & $\begin{array}{l}-0.010 \\
(0.009)\end{array}$ & $\begin{array}{l}-0.005 \\
(0.008)\end{array}$ \\
\hline Log(industry minimum wage) & & & $\begin{array}{c}0.002 \\
(0.002)\end{array}$ \\
\hline$t-1$ & & & $\begin{array}{r}0.003^{*} \\
(0.002)\end{array}$ \\
\hline$t-2$ & & & $\begin{array}{l}0.004^{* * *} \\
(0.001)\end{array}$ \\
\hline Dummy: Company is min wage company & & & $\begin{array}{l}-0.731 \\
(0.571)\end{array}$ \\
\hline$t-1$ & & & $\begin{array}{c}0.124 \\
(0.207)\end{array}$ \\
\hline$t-2$ & & & $\begin{array}{c}0.037 \\
(0.067)\end{array}$ \\
\hline $\begin{array}{l}\text { Over-identification test (Hansen) } \\
\text { (Degrees of freedom) }\end{array}$ & $\begin{array}{c}45.64 \\
(37)\end{array}$ & $\begin{array}{c}43.71 \\
(35)\end{array}$ & $\begin{array}{c}48.28 \\
(39)\end{array}$ \\
\hline [p-value] & {$[0.156]$} & [0.148] & [0.147] \\
\hline $\begin{array}{l}\text { AR(1) } \\
\text { [p-value] }\end{array}$ & $\begin{array}{l}-13.99 \\
{[0.000]}\end{array}$ & -13.19 & $\begin{array}{l}-13.30 \\
{[0.000]}\end{array}$ \\
\hline $\begin{array}{l}{[p \text {-value }]} \\
A R(2)\end{array}$ & $\begin{array}{c}{[0.000]} \\
-1.23\end{array}$ & $\begin{array}{l}{[0.000]} \\
-1.12\end{array}$ & $\begin{array}{c}{[0.000]} \\
-1.24\end{array}$ \\
\hline [p-value] & [0.219] & {$[0.263]$} & {$[0.214]$} \\
\hline
\end{tabular}

Notes: (i) See notes to Table V. (ii) All regressions use difference GMM estimates. (iii) Excluded instruments used are the same as in the model of column (8) of Table V. 
Table VII

Estimated Incidences and Elasticities

\begin{tabular}{|c|c|c|c|c|c|c|}
\hline & \multicolumn{2}{|c|}{$\begin{array}{l}\text { Table VI column } \\
\text { (3) }\end{array}$} & \multicolumn{2}{|c|}{$\begin{array}{l}\text { Table VIII column } \\
\text { (2) }\end{array}$} & \multicolumn{2}{|c|}{$\begin{array}{l}\text { Table VIII column } \\
\text { (3) }\end{array}$} \\
\hline & \multicolumn{2}{|c|}{ Full Sample } & \multicolumn{2}{|c|}{$\begin{array}{l}\text { Stand-alone } \\
\text { Companies }\end{array}$} & \multicolumn{2}{|c|}{ Multinational Group } \\
\hline & Elasticity & Incidence & Elasticity & Incidence & Elasticity & Incidence \\
\hline \multicolumn{7}{|l|}{ Short run } \\
\hline $\begin{array}{l}\text { Tax bill per } \\
\text { employee } t\end{array}$ & $\begin{array}{l}-0.120 \\
(0.037)\end{array}$ & $\begin{array}{l}-0.637 \\
(0.195)\end{array}$ & $\begin{array}{l}-0.118 \\
(0.041)\end{array}$ & $\begin{array}{l}-0.687 \\
(0.239)\end{array}$ & $\begin{array}{l}-0.117 \\
(0.047)\end{array}$ & $\begin{array}{l}-0.586 \\
(0.237)\end{array}$ \\
\hline $\begin{array}{l}\text { Value } \\
\text { added per } \\
\text { employee } f\end{array}$ & $\begin{array}{c}0.498 \\
(0.121)\end{array}$ & $\begin{array}{c}0.222 \\
(0.054)\end{array}$ & $\begin{array}{c}0.521 \\
(0.151)\end{array}$ & $\begin{array}{c}0.269 \\
(0.078)\end{array}$ & $\begin{array}{c}0.415 \\
(0.155)\end{array}$ & $\begin{array}{c}0.168 \\
(0.063)\end{array}$ \\
\hline \multicolumn{7}{|l|}{ Long run } \\
\hline $\begin{array}{l}\text { Tax bill per } \\
\text { employee } t\end{array}$ & $\begin{array}{l}-0.093 \\
(0.031) \\
\end{array}$ & $\begin{array}{l}-0.493 \\
(0.164)\end{array}$ & $\begin{array}{l}-0.076 \\
(0.029)\end{array}$ & $\begin{array}{l}-0.439 \\
(0.171)\end{array}$ & $\begin{array}{l}-0.108 \\
(0.046)\end{array}$ & $\begin{array}{l}-0.543 \\
(0.230)\end{array}$ \\
\hline $\begin{array}{l}\text { Value } \\
\text { added per } \\
\text { employee f }\end{array}$ & $\begin{array}{c}0.558 \\
(0.093)\end{array}$ & $\begin{array}{c}0.249 \\
(0.041)\end{array}$ & $\begin{array}{c}0.611 \\
(0.114)\end{array}$ & $\begin{array}{c}0.315 \\
(0.059)\end{array}$ & $\begin{array}{c}0.531 \\
(0.136)\end{array}$ & $\begin{array}{c}0.214 \\
(0.055)\end{array}$ \\
\hline
\end{tabular}

Note: All values are evaluated at the average values of the variables from the estimation sample using the derivation provided in Appendix 1. Standard errors calculated using the delta method, are in parentheses. 
Table VIII

Difference GMM Estimates (standard error)

\begin{tabular}{|c|c|c|c|c|}
\hline $\begin{array}{c}\text { Dependent Variable } \\
\text { Log(wage rate) }\end{array}$ & $\begin{array}{c}\text { All companies } \\
(1)\end{array}$ & $\begin{array}{c}\text { Stand-alone } \\
\text { companies } \\
(2)\end{array}$ & $\begin{array}{c}\text { Multinational } \\
\text { companies } \\
\text { (3) }\end{array}$ & $\begin{array}{c}\text { Multinational } \\
\text { companies } \\
(4)\end{array}$ \\
\hline \multirow[t]{2}{*}{ Lagged log(wage rate) } & $0.135^{* * *}$ & 0.079 & $0.166^{* * *}$ & $0.093^{* *}$ \\
\hline & $(0.024)$ & $(0.066)$ & $(0.028)$ & $(0.040)$ \\
\hline \multirow[t]{2}{*}{$t-2$} & $0.031^{* * *}$ & -0.013 & $0.055^{* * *}$ & 0.014 \\
\hline & $(0.011)$ & $(0.023)$ & $(0.013)$ & $(0.016)$ \\
\hline \multirow[t]{2}{*}{ Log (tax bill per employee) } & $-0.120^{* * *}$ & $-0.118^{* * *}$ & $-0.117^{* *}$ & $-0.101^{* * *}$ \\
\hline & $(0.037)$ & $(0.041)$ & $(0.047)$ & $(0.033)$ \\
\hline \multirow[t]{2}{*}{$t-1$} & $0.036^{* * *}$ & $0.042^{* * *}$ & $0.029^{* *}$ & $0.028^{* *}$ \\
\hline & $(0.010)$ & $(0.013)$ & $(0.014)$ & $(0.014)$ \\
\hline \multirow[t]{2}{*}{$t-2$} & $0.007^{* * *}$ & 0.006 & 0.004 & -0.005 \\
\hline & $(0.003)$ & $(0.004)$ & $(0.003)$ & $(0.004)$ \\
\hline \multirow[t]{2}{*}{ Dummy: -ve or zero tax bill } & $0.361^{* * *}$ & $0.549^{* * *}$ & $0.391^{* * *}$ & 0.316 \\
\hline & $(0.088)$ & $(0.136)$ & $(0.142)$ & $(0.311)$ \\
\hline \multirow[t]{2}{*}{$t-1$} & $-0.089^{* * *}$ & $-0.149^{* * *}$ & -0.045 & 0.185 \\
\hline & $(0.021)$ & $(0.033)$ & $(0.034)$ & $(0.207)$ \\
\hline \multirow[t]{2}{*}{$t-2$} & $-0.011^{*}$ & $-0.025^{* * *}$ & 0.004 & 0.080 \\
\hline & $(0.006)$ & $(0.009)$ & $(0.010)$ & $(0.083)$ \\
\hline \multirow[t]{2}{*}{ Log (value added per employee) } & $0.889^{* * *}$ & $0.863^{* * *}$ & $0.837^{* * *}$ & $0.640^{* * *}$ \\
\hline & $(0.067)$ & $(0.068)$ & $(0.133)$ & $(0.105)$ \\
\hline \multirow[t]{2}{*}{$t-1$} & $-0.155^{* * *}$ & $-0.101^{* *}$ & $-0.122^{* * *}$ & $-0.111^{* * *}$ \\
\hline & $(0.023)$ & $(0.045)$ & $(0.037)$ & $(0.051)$ \\
\hline \multirow[t]{2}{*}{$t-2$} & $-0.025^{* * *}$ & -0.001 & -0.014 & -0.004 \\
\hline & $(0.009)$ & $(0.018)$ & $(0.013)$ & $(0.019)$ \\
\hline \multirow[t]{2}{*}{ Union density } & $0.013^{* *}$ & -0.007 & $0.020^{* *}$ & $0.023^{* * *}$ \\
\hline & $(0.006)$ & $(0.008)$ & $(0.009)$ & $(0.009)$ \\
\hline \multirow[t]{2}{*}{$t-1$} & 0.003 & -0.012 & 0.002 & -0.004 \\
\hline & $(0.006)$ & $(0.007)$ & $(0.010)$ & $(0.010)$ \\
\hline \multirow[t]{2}{*}{$t-2$} & -0.005 & $0.017^{*}$ & -0.017 & $-0.031^{* *}$ \\
\hline & $(0.008)$ & $(0.009)$ & $(0.014)$ & $(0.015)$ \\
\hline \multirow[t]{2}{*}{ Log(industry minimum wage) } & 0.002 & -0.002 & -0.001 & -0.001 \\
\hline & $(0.002)$ & $(0.002)$ & $(0.004)$ & $(0.005)$ \\
\hline \multirow[t]{2}{*}{$t-1$} & $0.003^{*}$ & -0.000 & $0.005^{*}$ & -0.000 \\
\hline & $(0.002)$ & $(0.002)$ & $(0.003)$ & $(0.003)$ \\
\hline \multirow[t]{2}{*}{$t-2$} & $0.004^{* * *}$ & -0.000 & $0.005^{* * *}$ & 0.001 \\
\hline & $(0.001)$ & $(0.002)$ & $(0.002)$ & $(0.002)$ \\
\hline \multirow[t]{2}{*}{ Dummy: Co. is min wage company } & -0.731 & -1.091 & -0.751 & -0.037 \\
\hline & $(0.571)$ & $(1.222)$ & $(1.090)$ & $(0.759)$ \\
\hline \multirow[t]{2}{*}{$t-1$} & 0.124 & -0.041 & -0.213 & -0.249 \\
\hline & $(0.207)$ & $(0.358)$ & $(0.523)$ & $(0.287)$ \\
\hline \multirow[t]{2}{*}{$t-2$} & 0.037 & -0.033 & -0.074 & -0.091 \\
\hline & $(0.067)$ & $(0.137)$ & $(0.169)$ & $(0.100)$ \\
\hline \multirow[t]{2}{*}{ Log (group tax bill per employee) } & & & & 0.010 \\
\hline & & & & $(0.018)$ \\
\hline \multirow[t]{2}{*}{$t-1$} & & & & -0.011 \\
\hline & & & & $(0.010)$ \\
\hline \multirow[t]{2}{*}{$t-2$} & & & & -0.003 \\
\hline & & & & $(0.003)$ \\
\hline
\end{tabular}


Table VIII

(continued)

\begin{tabular}{|c|c|c|c|c|}
\hline $\begin{array}{l}\text { Dependent Variable } \\
\text { Log(wage rate) }\end{array}$ & $\begin{array}{c}\text { All companies } \\
\text { (1) }\end{array}$ & $\begin{array}{c}\text { Stand-alone } \\
\text { companies } \\
(2)\end{array}$ & $\begin{array}{l}\text { Multinational } \\
\text { companies } \\
(3)\end{array}$ & $\begin{array}{c}\text { Multinational } \\
\text { companies } \\
(4)\end{array}$ \\
\hline Dummy: -ve or zero group tax bill & & & & $\begin{array}{l}-0.062 \\
(0.093)\end{array}$ \\
\hline$t-1$ & & & & $\begin{array}{l}-0.014 \\
(0.047)\end{array}$ \\
\hline 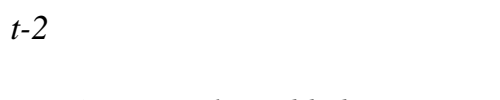 & & & & $\begin{array}{l}-0.006 \\
(0.020)\end{array}$ \\
\hline $\begin{array}{l}\text { Log (group value added per } \\
\text { employee) }\end{array}$ & & & & $\begin{array}{c}0.074 \\
(0.063)\end{array}$ \\
\hline$t-1$ & & & & $\begin{array}{c}0.015 \\
(0.049)\end{array}$ \\
\hline$t-2$ & & & & $\begin{array}{c}0.003 \\
(0.006)\end{array}$ \\
\hline$A R(1)$ & -13.30 & -9.61 & -5.55 & -5.13 \\
\hline $\begin{array}{l}\text { [p-value] } \\
A R(2)\end{array}$ & $\begin{array}{c}{[0.000]} \\
-1.24\end{array}$ & $\begin{array}{c}{[0.000]} \\
-1.97\end{array}$ & $\begin{array}{c}{[0.000]} \\
-1.11\end{array}$ & $\begin{array}{c}{[0.000]} \\
-1.74\end{array}$ \\
\hline [p-value] & {$[0.214]$} & {$[0.048]$} & {$[0.265]$} & {$[0.081]$} \\
\hline $\begin{array}{l}\text { Overid. restrictions test (Hansen) } \\
\text { (Degrees of freedom) } \\
\text { [p-value] }\end{array}$ & $\begin{array}{c}48.28 \\
(39) \\
{[0.147]}\end{array}$ & $\begin{array}{c}23.37 \\
(19) \\
{[0.221]}\end{array}$ & $\begin{array}{c}23.24 \\
(19) \\
{[0.227]}\end{array}$ & $\begin{array}{c}40.00 \\
(30) \\
{[0.105]}\end{array}$ \\
\hline Observations & 166,749 & 62,955 & 56,883 & 35,820 \\
\hline Number of companies & 55,082 & 19,399 & 19,348 & 13,717 \\
\hline
\end{tabular}

Note: (i) See notes to Table VII; (ii) Additional excluded instruments used in columns (2) and (3) were firstdifferences of EMTR, EATR, statutory corporate tax rate, third order lags of log (tangible fixed assets as a proportion of total fixed assets if positive), log (non-current liabilities as a proportion of total assets if positive) and binary indicators for: non-positive profits excluding taxes, zero tangible fixed assets and non-current liabilities; Additionally, third order lags of the group level variables of the additional instruments used in columns (2) and (3) were also used in column (4); (iii) The group variables are calculated by adding up the values for the subsidiaries present in the dataset, excluding the company concerned. The group tax bill and value added are divided by the employment of the subsidiary. 
Appendix 1 - Derivation of Elasticities and Incidences with respect to value added per employee and taxation per employee

Using the same notation as in the main paper and suppressing dynamics for simplicity, write the estimated equation (with all variables expressed in per employee terms) as:

$$
\ln w=\beta_{1} \ln f+\beta_{2} \ln t
$$

where

$$
t=\tau(f-w)+\tilde{\phi}
$$

Differentiating, holding $f$ constant $(d f=0)$ generates

$$
\frac{d w}{d t}=\beta_{2}\left(\frac{w}{t}\right)
$$

Differentiating, holding $\tilde{\phi}$ constant $(d \tilde{\phi}=0)$ generates

$$
\frac{d w}{d f}=w\left[\frac{\beta_{1}}{f}+\frac{\beta_{2} \tau}{t}\right] /\left[1+\frac{\beta_{2} w \tau}{t}\right] .
$$

The elasticities are calculated by multiplying the above incidences by the relevant ratios:

$$
\begin{aligned}
& \frac{d \ln w}{d \ln f}=\frac{f}{w} \frac{d w}{d f} \\
& \frac{d \ln w}{d \ln t}=\frac{t}{w} \frac{d w}{d t}=\beta_{2}
\end{aligned}
$$

Long run incidences and elasticities are calculated by using the relevant LR coefficients instead of the $\beta \mathrm{s}$ in the above expressions. 


\section{Appendix 2}

Table IA

Persistence of Wage Rate and Value Added per Worker. Simple Univariate AR Models.

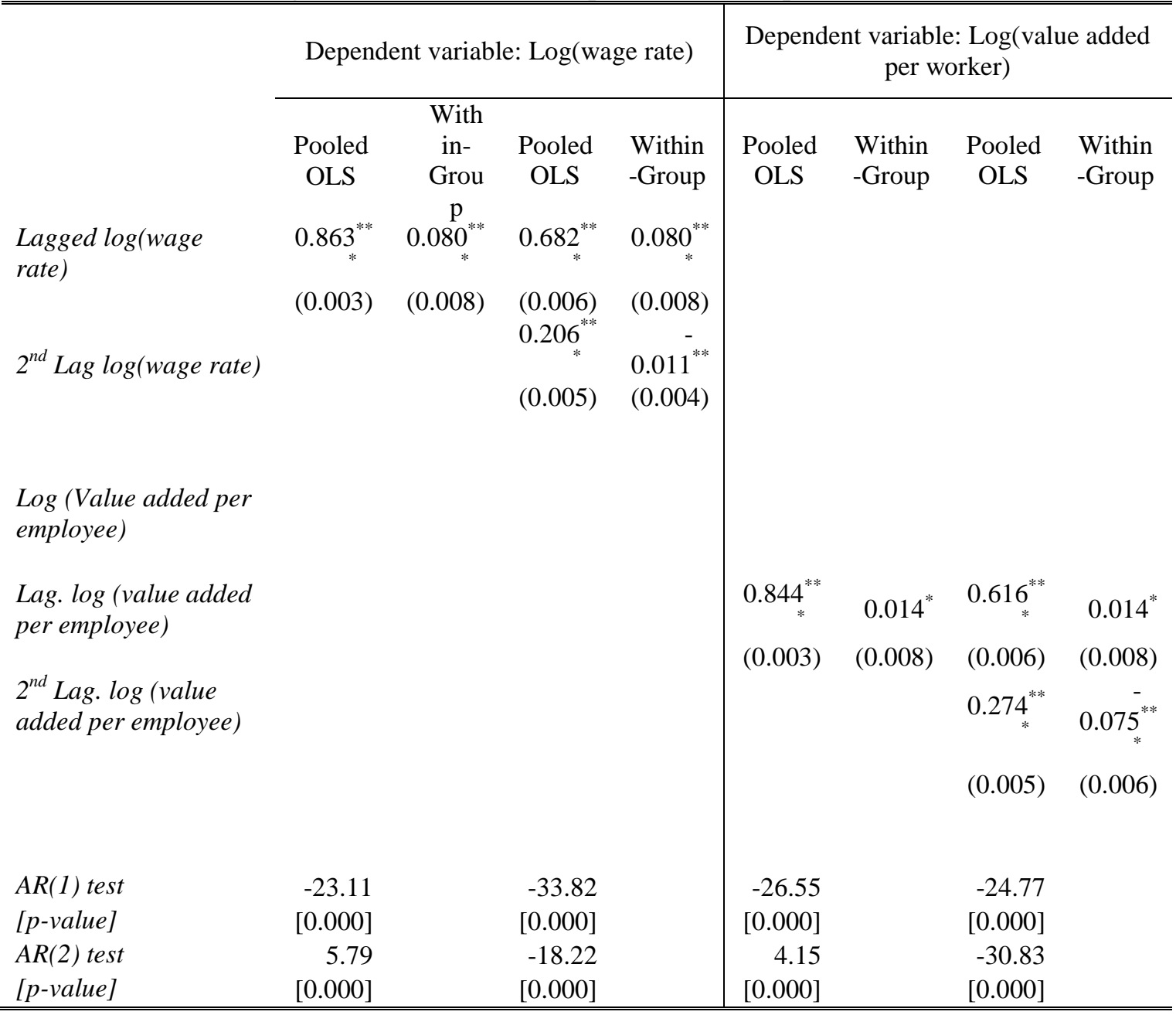

Notes: (i) Time dummies are included in all of the above. (ii) The equations were estimated on the same sample as the one used in the main tables using 55,082 companies giving a total of 166,749 observations; (iii) standard errors in parenthesis unless otherwise stated. (iv) *** significant at $1 \%$ level; ** significant at $5 \%$ level; * significant at $10 \%$ level. 